This is the peer reviewed version of the following article: Ezcurra, R, Rios, V. Quality of government and regional resilience in the European Union. Evidence from the Great Recession. Pap Reg Sci. 2019; 98: 1267- 1290, which has been published in final form at https://doi.org/10.1111/pirs.12417. This article may be used for non-commercial purposes in accordance with Wiley Terms and Conditions for Use of Self-Archived Versions.

\title{
Quality of government and regional resilience in the European Union. Evidence from the Great Recession
}

\author{
Roberto Ezcurra \\ Department of Economics and INARBE \\ Universidad Pública de Navarra \\ E-mail: roberto.ezcurra@unavarra.es \\ Vicente Rios \\ Department of Economics \\ Universidad Pública de Navarra \\ E-mail: vicente.rios@unavarra.es
}

Final version 


\begin{abstract}
This paper examines the relationship between quality of government and regional resilience in the European Union during the Great Recession. The results show that the quality of government is an important factor when shaping the regional reaction to the crisis. Our estimates reveal that higher quality of government is associated with greater regional resilience over the Great Recession. This is partly due to the role played in this context by spatial spillovers induced by the quality of government in neighbouring regions. The observed link between governance and regional resilience is robust to the inclusion in the analysis of different explanatory variables that may affect both government quality and regional resilience. Likewise, our findings do not depend on the specific dimension of governance considered, the estimation method or the econometric specification employed to capture the nature of spatial spillovers.
\end{abstract}

Keywords: quality of government, regional resilience, European Union, Great Recession.

JEL classification: H11, R12. 


\section{Introduction}

The Great Recession that started in 2008 has affected Europe more severely than any other crisis since the end of the Second World War (Capello and Caragliu, 2016). Although the roots of this major economic downturn have to do with the collapse of the United States housing bubble and the excessive expansion of credit, its consequences immediately spread across the whole of Europe. By mid-2009, GDP per capita in the European Union (EU) had already decreased by $5 \%$ compared with the fourth quarter of 2007, whereas unemployment increased from 7 to 11\% between 2007 and 2013 (Fratesi and Rodríguez-Pose, 2016). Nevertheless, the impact of the crisis has been highly uneven across Europe, both between countries as well as between regions within countries (e.g. Groot et al., 2011; Capello et al., 2015; Christopherson et al., 2015). Taking into account the long-lasting economic and social effects of the Great Recession, it is especially important to examine what might account for this geographical variation. To address this issue, one should investigate the factors behind regional economic resilience, which can be defined as "the capacity of a regional or local economy to withstand or recover from market, competitive and environmental shocks to its developmental growth path, if necessary by undergoing adaptive changes to its economic structures and its social and institutional arrangements, so as to maintain or restore its previous developmental path, or transit to a new sustainable path characterized by a fuller and more productive use of its physical, human and environmental resources" (Martin and Sunley, 2015, p. $13)$.

The literature on regional economic resilience has considerably grown in recent 
years. ${ }^{1}$ From an empirical perspective, this literature has highlighted the relevance of different factors in shaping regional reactions to external shocks, including the sectoral composition of economic activity and its degree of diversity, the endowment of human capital, the intensity of innovation activities, labour market characteristics, urbanization patterns, or national macroeconomic conditions (e.g. Davies, 20011; Martin, 2012; Brakman et al., 2015; Crescenzi et al., 2016a; Giannakis and Bruggeman, 2017). However, as far as we are aware, the potential influence of the quality of government on regional resilience has received no attention in this literature. ${ }^{2}$ This omission is especially disconcerting, given that, as we will see below, there are several reasons to assume that the way in which governments comply with their obligations and administer public services should affect the ability of regions to withstand recessionary shocks. In order to fill this gap, the present paper aims to examine the relationship between quality of government and regional resilience in the EU during the Great Recession, using data on 255 NUTS2 regions from 27 different countries. ${ }^{3}$ In particular, we are interested in finding out to what extent governance outcomes can contribute to mitigating the impact of the Great Recession at the regional level.

A second main contribution of the paper has to do with the methodological approach adopted to investigate the link between quality of government and regional resilience. Unlike previous studies on the determinants of regional resilience in the European con-

\footnotetext{
${ }^{1}$ For recent surveys, see the 2016 special issue of Regional Studies on "Resilience revisited", or the 2018 special issue of The Annals of Regional Science on "Regional determinants of economic resilience".

${ }^{2}$ Nevertheless, there is abundant evidence of the importance of the quality of government for economic development. Most of these studies have generally focused on countries in the world (e.g. Hall and Jones, 1999; Kaufmann and Kraay, 2002; Rodrik et al., 2004), although there are also analyses at the regional level (e.g. Rodríguez-Pose and Garcilazo, 2015; Ketterer and Rodríguez-Pose, 2018).

${ }^{3}$ NUTS is the French acronym for "Nomenclature of Territorial Units for Statistics", a hierarchical classification of subnational spatial units established by Eurostat according to administrative criteria. In this classification, NUTS0 corresponds to the country level, while increasing numbers indicate increasing levels of territorial disaggregation.
} 
text, in our paper the sample regions are not treated as isolated units that evolve independently of the rest, and spatial effects are formally incorporated into the analysis. This approach allows us to explore the role played by spatial spillovers in explaining the effect of the quality of government on regional resilience in the EU, and to consider the potential existence of spatially correlated shocks that may affect regional economic performance over the study period. Thus, our analysis explicitly takes into account the possibility that the impact of the Great Recession in any given region is influenced by the conditions in neighbouring regions.

The results of the paper show that the quality of government is an important factor when shaping the regional reaction to the crisis in the EU. Our estimates reveal that higher quality of government is associated with greater regional resilience over the Great Recession. This is partly due to the role played in this context by spatial spillovers induced by the quality of government in neighbouring regions. The observed link between governance and regional resilience is robust to the inclusion in the analysis of different explanatory variables that may affect both government quality and regional resilience. Likewise, our findings do not depend on the specific dimension of governance considered, the estimation method or the econometric specification employed to capture the nature of spatial spillovers.

The remainder of the paper is structured as follows. After this introduction, section 2 discusses from a theoretical point of view why the quality of government should affect regional resilience. Section 3 describes the measures of governance and regional resilience used in the paper. In turn, section 4 presents the results of the empirical analysis carried out to investigate the connection between quality of government and regional resilience. The final section offers the main conclusions from the paper. 


\section{Why should the quality of government affect re- gional resilience?}

There are various reasons to assume that the quality of government is related to regional resilience. To begin with, government performance may affect the type, frequency and intensity of the shocks experienced by regional economies. This is particularly evident in the case of financial shocks, such as the one in the origin of the Great Recession. As a result of financial shocks, leveraged firms find themselves in a position in which their liquidity is called back by the lender, which in turn has a direct effect on firms ability to run and manage existing jobs (Boeri et al., 2012). Consequently, firms may be forced to cut their investments, shut down part of their business activity and destroy jobs. The quality of government can play a crucial role in this context, minimizing the vulnerability of the economy to adverse financial shocks, given that well-regulated capital markets are likely to experience less intense crises (OECD, 2017). Corruption, which is a central element of the quality of government, can also undermine financial stability. In a setting with a high level of corruption, practices such as lending tend to be more frequent, which

reduces the quality of the loan portfolio of banks and increase concentration risk (La Porta et al., 2003). In this regard, impartial institutional settings that remove policy distortions favouring debt over equity financing and promote a greater diversification of financing instruments, may strengthen regional resilience through increased financial stability (Caldera-Sánchez and Gori, 2016). Supporting this line of argumentation, Ahrend and Goujard (2012) show that larger debt bias in cross-border flows is associated with a greater incidence of financial crises, while Sondermann (2016) finds that the quality of government tends to reduce the frequency of crises. In a similar vein, the 
empirical evidence provided by Honing (2008) indicates that good governance outcomes decrease the likelihood of sudden stop of capital inflows.

Moreover, the quality of government is likely to affect the level of systemic uncertainty, which could have sizeable effects on the degree of vulnerability of regional economies by determining the dynamic path of investment and employment rates (Acemoglu et al., 2003; Bloom, 2009). The intuition behind this argument is that the institutional environment drives systemic uncertainty, and systemic uncertainty affects economic performance and resilience. This mechanism operates through the so-called depressive macroeconomic uncertainty effect, which usually leads to the "wait-and-see" behaviour that is typical during periods of crisis, where investment rates fall, labour demand and employment decrease and economic growth drops. Supportive evidence on the link between low quality of government and uncertainty is provided by different authors. For example, Calderón et al. (2016) find that in economies with low quality of government the implementation of policy is pro-cyclical, which increases fluctuations driving up overall uncertainty. Likewise, there are numerous studies showing the existence of a negative association between corruption and economic performance (e.g. Mauro, 1995; Tanzi and Davoodi, 1997; Aidt, 2009).

The quality of government can also affect the ability of regional economies to react to recessionary shocks by increasing the dynamism of the private sector. Impartial legislations and regulations that contribute to promoting private sector development can strengthen antitrust enforcement, minimize barriers of entry and decrease privileges of established firms (OECD, 2010). This favours the development of entrepreneurship, which is particularly important to withstand and recover from recessionary shocks (Nistotskaya et al., 2015). Following Schumpeter (1942), Aghion and Saint-Paul (1998) show 
that periods of recession where creative destruction is likely to be at work can have a potentially beneficial effect on growth paths if older technologies are replaced by newer ones. Nevertheless, the creative-destruction process may not work if entry barriers are high and if government regulations, instead of promoting a fair competition, favour certain agents. In this regard, Campos et al. (2010) find that corruption can represent an important barrier for new firms, enhancing monopoly power and rents earned by incumbent firms. This is consistent with the evidence provided by Sutherland and Hoeller (2013), who show that stringent product market regulations reduces ex-post resilience by increasing the persistence of economic downturns. In turn, Rodríguez-Pose and Di Cataldo (2015) find that the quality of government affects innovative performance at the regional level, which confirms the existence of a positive connection between governance and regional competitiveness. In fact, as Putnam (2000, p. 325) argues, "institutional factors are the key enablers of innovation, mutual learning and productivity growth".

At the same time, the quality of government may be related to regional resilience through its positive impact on the overall efficiency of the judicial system. The efficiency of the judicial system affects the time and cost for resolving commercial disputes in a local first-instance court, but also bankruptcy procedures. Efficient bankruptcy regulations are crucial to allow for low-cost exit of less productive and insolvent firms, thus improving resource reallocation (OECD, 2017). Hence, by strengthening market selection and resource reallocation, an impartial and efficient judicial system can increase the capacity of regional economies to absorb recessionary shocks. Moreover, the quality of government, minimizing the discrimination between lenders and borrowers in the resolution of bankruptcies, may also help to address the negative effects of non-performing loans in periods of crisis by developing a suitable debt restructuring framework, thus 
providing incentives for banks to invest rather than freezing capital movements.

An alternative explanation of the potential link between quality of government and regional resilience has to do with the impact of governance outcomes on the efficiency of public investment (e.g. Tanzi and Davoodi, 1997; Esfahani and Ramírez, 2003). Regions with low quality of government are generally characterized by the presence of persistent corruption, pervasive rent-seeking, self-serving decision-makers, and low quality of bureaucracy. This set of problems often gives rise to imperfectly functioning markets and institutional and government failure, which in turn reduces the capacity of the public sector to design and implement effective policies that contribute to improving the ability of regional economies to withstand and recover from recessionary shocks. In fact, the evidence provided by Rodríguez-Pose and Garcilazo (2015) and Crescenzi et al. (2016b) shows that the quality of government is an important factor when determining the returns of public investment in the European regions.

A relatively low quality of government in any given region has a negative impact on the business climate, which directly affects the probability of receiving foreign direct investment (FDI). On the contrary, regions with better governance outcomes tend to attract greater FDI (Fazio and Talamo, 2008; Rodríguez-Pose and Cols, 2017). A high dependency of FDI increases the degree of exposure of regional economies to external shocks, raising their vulnerability. Nevertheless, the final impact on regional resilience is ambiguous because FDI can also help to improve economic performance in the host region through the transfer of new technologies and know-how, and the creation of linkages between foreign and domestic firms (OECD, 2017).

As can be seen, most of the different arguments laid down above point to the exis- 
tence of a positive relationship between quality of government and regional resilience. However, despite its importance from a policy perspective, the potential link between governance and regional resilience has not been empirically tested so far. In order to fill this gap and complement the literature on the determinants of regional resilience, the rest of the paper is devoted to investigating this issue in a cross-section of European regions.

\section{Measuring regional resilience and quality of gov- ernment}

Our study requires data on the degree of resilience of EU regions during the Great Recession. Although the number of papers on regional resilience has significantly grown in recent years, there is not an unanimous agreement about how to measure this concept and different approaches have been applied in the literature (Martin and Sunley, 2015; Doran and Fingleton, 2016). The majority of authors use univariate indices capturing changes in the level of economic activity (e.g. Fingleton et al., 2012; Martin, 2012; Crescenzi et al., 2016a), even though there are also studies based on the information

provided by composite indicators (e.g. Rizzi et al., 2018; Staníčková and Melecký, 2018). Against this background, and taking into account the nature of our study, we resort to a widely used measure of regional resistance to recessionary shocks (Lagravinese, 2015; Martin et al., 2016; Giannakis and Bruggeman, 2017):

$$
R E S_{i}=\frac{\Delta E_{i}-\Delta E_{E U}}{\left|\Delta E_{E U}\right|}
$$


where $\Delta E_{i}$ is the change in the employment rate in region $i$ during the crisis period 2008-2013 (see Figure A1 in the online Appendix for further details). In turn, $\Delta E_{E U}$ stands for the average variation in the employment rate in the EU regions between 2008 and 2013. A positive value of this index means that region $i$ exhibits greater resistance to a recessionary shock than the EU average, while a negative value implies that region $i$ is less resistant than the EU average. $R E S_{i}$ equals to zero when there is no difference in the variation of the employment rate in region $i$ and the EU average. As is usual in the literature, this measure of regional resilience concentrates on the capacity of regional labour markets to adapt to adverse shocks. We consider that this approach is more informative in this context than focussing on output changes, as variations in employment better reflect the social impact of the Great Recession (Giannakis and Bruggeman, 2017). Although output is undoubtedly important from an economic perspective, the employment rate is often more relevant for the welfare of ordinary citizens than the creation of value added. This argument is particularly relevant nowadays in view of the situation of many countries of the European periphery, where the recovery from the Great Recession has often been jobless (Fratesi and Rodríguez-Pose, 2016).

We calculate the index of regional resilience just described for 255 NUTS2 regions in the EU27, ${ }^{4}$ using data drawn from Eurostat for the crisis period 2008-2013. ${ }^{5}$ The results are displayed in Figure 1. As can be observed, the impact of the Great Recession has been far from homogeneous across the EU, and there are important geographical

\footnotetext{
${ }^{4}$ NUTS2 regions are used instead of other possible alternative for two reasons. First, NUTS2 is the territorial unit most commonly used in the literature on regional resilience in the EU (e.g. Brakman et al., 2015; Giannakis and Bruggeman, 2017; Rizzi et al., 2018), which facilitates the comparison of our findings with those obtained in earlier studies. Second, NUTS2 regions are the basic unit for the application of cohesion policies in the EU.

${ }^{5}$ The regional employment rates have been calculated as the ratio between the number of employed persons and active population aged 15-64. These figures come from the EU Labour Force Survey (EULFS), which follows the definitions and recommendations of the International Labour Organisation (ILO).
} 
differences. The countries in the Southern periphery of Europe (i.e. Portugal, Spain, Italy, Greece and Cyprus) have been particularly hard hit (Fingleton et al., 2014; Fratesi and Rodríguez-Pose, 2016). Likewise, the labour markets of Ireland and Bulgaria have shown relatively low levels of resistance to the economic downturn. On the contrary, Germany, where employment continued to grow during the crisis, exhibits the best performance. Austria, Belgium, Finland and Sweden also show relatively high values of the resilience index. The observed differences between countries, however, do not hide the existence of important within-country disparities (Groot et al., 2011; Capello et al., 2015; Giannakis and Bruggeman, 2017). This is particularly evident in countries such as France, Italy, the Netherlands, Romania or the United Kingdom.

\section{INSERT FIGURE 1 AROUND HERE}

In order to carry out our research, we also need information on the quality of government in the EU regions. To that end, we resort to the European Quality of Government Index (EQI), which has recently been constructed with the aim to provide scholars and policy makers with a comparable and homogeneous measure of governance at the regional level that can be used to make comparisons within and across countries in Europe (Charron et al., 2014, 2015). The EQI is based on survey data about the perceptions and experiences of European citizens on the quality, impartiality and level of corruption in education, public health care and law enforcement. In order to obtain the EQI score for the various regions, the information provided by the survey data is combined with four of the six Worldwide Governance Indicators (WGI) developed by Kaufmann et al. (1999): Voice and accountability, Government effectiveness, Rule of law, and Control of 
Corruption. ${ }^{6}$ So far, the EQI is available for three years: 2010, 2013 and 2017. Given that we are interested in examining regional performances during the Great Recession, we employ as our main independent variable the average values for years 2010 and $2013 .^{7,8}$

Figure 2 provides a graphical illustration on the association between quality of government and regional resilience in the EU during the Great Recession. ${ }^{9}$ The scatter plot suggests the existence of a positive relationship between governance outcomes and regional resilience during the crisis. This means that regions with better quality of government tend to be more resilient, while those regions with worse governance outcomes are characterized on average by a lower resistance to the Great Recession. Indeed, the pairwise correlation between the two variables is statistically significant $(\rho=0.40$ with p-value $=0.000)$. Nevertheless, the information provided by Figure 2 should be treated with caution, as the observed connection between quality of government and regional resilience may simply be a spurious correlation resulting from the omission of other variables affecting both governance and regional labour market performance. In view of this potential problem, in the next section we develop a more appropriate statistical analysis on the link between quality of government and regional resilience.

\section{INSERT FIGURE 2 AROUND HERE}

\footnotetext{
${ }^{6}$ See Charron et al. $(2014,2015)$ for further details on the methodology used to construct the EQI.

${ }^{7}$ The results of the analysis remain unaltered if the EQI values for 2010 are used.

${ }^{8}$ The EQI is available for all EU27 countries at NUTS2 regional level, with the exception of Belgium, Germany, Greece, Hungary, Sweden and the United Kingdom, for which the data are provided at NUTS1 level. For these six countries we follow Rodríguez-Pose and Di Cataldo (2015) and Ketterer and Rodríguez-Pose (2018), and assign the same EQI score to all NUTS2 regions nested within the bigger NUTS1 regions.

${ }^{9}$ In order to facilitate the interpretation, the various variables used to construct the graphic were normalized to make them range from 0 to 100. This transformation of the measures of regional resilience and quality of government is also used in the regression analyses in the next section.
} 


\section{Econometric approach}

\subsection{Model specification and estimation procedure}

When considering the choice of an econometric specification to investigate the connection between quality of government and regional resilience, it is important to note that Figure 1 suggests that the capacity of resistance to the Great Recession is not randomly distributed across space in the EU. On the contrary, there seems to be spatial clusters of regions with similar levels of resilience to the crisis, while there are relatively few cases in which a region shows a markedly different performance from its neighbours. This is consistent with the evidence provided by Figure 3, which reveals the existence of a positive and strong link between own resilience and the average of neighbouring regions. ${ }^{10}$ In fact, the pairwise correlation between the two is 0.89 with p-value $=$ 0.000. In order to confirm this spatial pattern, we calculate the Moran's I test of spatial autocorrelation. The result (I statistic is 0.766 with p-value $=0.00$ ) leads to the rejection of the null hypothesis of absence of spatial autocorrelation in the distribution of regional resilience. This means that the regional distribution of high and/or low values of the measure of resilience in equation (1) is more spatially clustered than would be expected if the underlying spatial processes were random. The implications of this issue are potentially important from an econometric perspective (Anselin, 1988). For this reason, we consider the following cross-sectional model:

$$
\mathbf{R E S}=\alpha \iota_{n}+\lambda \mathbf{W R E S}+\beta \mathbf{Q G}+\mathbf{X} \boldsymbol{\gamma}+\mathbf{u}
$$

\footnotetext{
${ }^{10}$ The definition of neighbouring regions used here is based on physical contiguity. To ensure that every region has at least one neighbour, we employ the Delaunay triangulation by constructing Voronoi polygons from the centroids of the sample regions. See LeSage and Pace (2009, p. 118) for further details.
} 
with

$$
\mathbf{u}=\rho \mathbf{W u}+\boldsymbol{\epsilon}
$$

where RES and QG are, respectively, $n \times 1$ vectors consisting of one observation for each region in the sample $(i=1, \ldots, n)$ on the measures of regional resilience and quality of government described in section 3 . $\mathbf{X}$ is a $n \times k$ matrix of a set of variables that control for different factors that are assumed to have an influence on regional resilience. $\mathbf{W}$ is a $n \times n$ spatial weights matrix with non-negative elements indicating how the regions in the sample are spatially interconnected. Its diagonal elements are equal to zero by assumption, since no region can be viewed as its own neighbour. In turn, $\mathbf{u}$ is a $n \times 1$ disturbance vector, while $\boldsymbol{\epsilon}$ is the corresponding $n \times 1$ innovation vector. Given the nature of our data, the innovations are assumed to be independent but heteroskedastically distributed, where the heteroskedasticity is of unknown form. Our main interest throughout the paper is in coefficient $\beta$, which captures the effect of the quality of government on regional resilience.

\section{INSERT FIGURE 3 AROUND HERE}

This model is a fairly general specification that includes two different spatial processes potentially relevant in our context. The first one, captured by the spatial lag of

the dependent variable (WRES), has to do with the possible presence of direct spatial spillovers between neighbouring regions related to their capacity of resistance to recessionary shocks, which would be consistent with the preliminary evidence provided by 
Figure 3. The second one, captured by the spatial autoregressive process in the disturbance term, additionally allows us to consider spatial spillovers between specific features of the environment that may affect regional resilience. Given that neighbouring regions tend to share many of these specific features, the inclusion of the spatial autoregressive process in the model is necessary for consistent estimation of standard errors (Kelejian et al., 2013). This spatial autoregressive model with autoregressive disturbances of order $(1,1)$ is often known as a $\operatorname{SARAR}(1,1)$ model (Anselin and Florax, 1995).

The inclusion of the spatial lag of the dependent variable in the list of regressors in equation (2) implies that the OLS estimator will not be consistent (Anselin, 1988). In view of this, we resort to the generalized spatial two stage least squares (GS2SLS) estimator derived by Kelejian and Prucha $(1998,1999,2010)$ and extended by Arraiz et al. (2010) and Drucker et al. (2013), which implements a multistep estimation strategy based on the generalized method of moments (GMM) and instrumental variables (IV) to estimate the parameters of the model. ${ }^{11}$ This estimator provides consistent estimates even when the innovations of the disturbance process in equation (3) are heteroskedastically distributed over the observations. This is especially relevant in our context, as the sample regions are heterogeneous in important characteristics (e.g. size), which causes one to suspect that the innovations of the disturbance process are hetorskedastic. ${ }^{12}$

\footnotetext{
${ }^{11}$ See Arraiz et al. (2010) or Drucker et al. (2013) for further technical details on the estimation method.

${ }^{12} \mathrm{An}$ additional concern when estimating the $\operatorname{SARAR}(1,1)$ model in equations $(2)$ and $(3)$ has to do with the possible endogeneity of the measure of quality of government. We address this potential problem in section 5.2 .
} 


\subsection{Control variables}

Our choice of control variables is mainly guided by the need to account for factors which may affect both regional resilience and the quality of government and, consequently, whose omission might bias the estimated effect of governance on regional resilience. On the basis of a review of the recent literature on regional resilience, our $\operatorname{SARAR}(1,1)$ model incorporates various controls related to the sectoral composition of economic activity and regional specialization, human capital and innovation activities, or the degree of regional autonomy. We now describe these controls and provide a brief conceptual justification for their inclusion in the analysis. ${ }^{13}$

\section{The sectoral composition of economic activity and regional specialization}

The sectoral composition is often considered as a key factor in explaining why regions differ in their resilience to economic downturns such as the Great Recession (e.g. Davies, 2011, Brackman et al., 2015; Martin et al., 2016). Some economic activities are more vulnerable to changes in the business cycle than others, and as such suffer the most from recessionary shocks. This is the case of manufacturing and construction, which traditionally are the most affected sectors during an economic crisis (Martin, 2012). Conversely, other activities are more impervious to fluctuations in the business cycle. For example, regions with higher levels of public employment are more protected from downturns in the cycle, since they experience less job destruction during economic crises. Likewise, the degree of protection and regulation of agricultural markets in the EU implies that regions with relatively large agricultural sectors tend to be less exposed

\footnotetext{
${ }^{13}$ Table A1 in the online Appendix presents the detailed definitions and sources of all the control variables used in the paper. Several descriptive statistics are included in Table A2.
} 
to changes in the business cycle (Rodríguez-Pose and Fratesi, 2007; Lagravinese, 2015; Fratesi and Rodríguez-Pose, 2016). In view of this, we control for the shares of regional employment in agriculture, manufacturing, and non-market services. ${ }^{14}$

In addition to the sectoral composition of economic activity, its degree of diversity may also be relevant in this context (Martin et al., 2016). The neoclassical trade model suggests that regions should specialize in those activities in which they enjoy a comparative advantage over their trade partners. Indeed, the existence of external economies also leads to specialization at the industry level. At the same time, a region with an excessive reliance on a small number of activities is potentially more vulnerable and unstable in case of a downturn, as it has much less scope to provide some measure of buffering against the perturbation (Malizia and Ke, 1993; Trendle, 2006). On the contrary, a diverse economic structure should allow a regional economy to "spread risk", thus reducing the intensity of cyclical fluctuations and increasing regional resilience (Baldwin and Brown, 2003; Ezcurra, 2011). ${ }^{15}$ Accordingly, our baseline model also incorporates a Herfindahl index to capture the degree of sectoral diversification in the sample regions. This specialization index is as follows:

$$
S P E_{i}=\sum_{s=1}^{S} e_{i s}^{2}
$$

where $e_{i s}$ is the employment share of region $i$ in sector $s$. The value of the Herfindahl

\footnotetext{
${ }^{14}$ In order to minimize any potential problem of reverse causality, all the time-varying controls described in this section enter in the model as their respective means over the pre-crisis period 2000-2007. The only exception is the indicator of regional autonomy, which refers to the period 2000-2005. This strategy is consistent with the approach adopted in earlier studies on the determinants of regional performance in Europe during the Great Recession (e.g. Groot et al., 2011; Crescenzi et al., 2016a; Giannakis and Bruggeman, 2017).

${ }^{15}$ The type of industrial diversity may also be important in this context. In fact, Frenken et al. (2007) claim that diversity in related industries ("related variety") enhances knowledge spillovers and has a positive effect on employment growth.
} 
index ranges from $\frac{1}{S}$ when employment is evenly distributed across the $\mathrm{S}$ sectors, to 1 when all the employment is concentrated in the same sector. Therefore, the higher the value of $S P E_{i}$, the less sectorally diverse is the region in question.

The sectoral composition of economic activity may affect the institutional framework (Nunn, 2007), which points to the possible existence of a connection between regional specialization and the quality of government. This means that any observed association between government quality and regional resilience may be spurious if industry mix and the degree of sectoral diversification are ignored.

\section{Human capital and innovation}

Among the determinants of regional competitiveness, the endowment of human capital and innovation activities play a key role in explaining the ability of a region to react to a recessionary shock (Chapple and Lester, 2010; Di Caro, 2017). This has to do with the close connection between both factors and the capacity of regional economies to absorb externally generated new ideas and create new knowledge (Crescenzi, 2009; Crescenzi and Rodríguez-Pose, 2011). Although this is important in all phases of the economic cycle, its relevance increases during a crisis. For example, as pointed out by Crescenzi et al. (2016a), an innovation-prone regional environment can contribute to alleviating the negative consequences of the crisis not only by developing new products and/or new technologies, but also by fostering organizational innovation and the reduction of production costs to maintain regional competitiveness. Furthermore, regions with high levels of human capital and innovation activities are in better position to attract the most sophisticated and high-value-added functions of multinational firms, thus increasing 
the regional resistance to adverse economic disturbances (Crescenzi et al., 2014). For this reason, we include in the list of regressors in equation (2) the population share with tertiary education and the number of patents per inhabitant, as proxies for the endowment of human capital and the intensity of innovation activities in the sample regions. ${ }^{16}$ At this point it is important to note that these variables may also be correlated with the quality of government at the regional level (Rodríguez-Pose and Di Cataldo, 2015). Consequently, their inclusion in our baseline model is especially necessary in order to estimate the impact of governance on regional resilience independently of the effect of these covariates.

\section{Regional autonomy}

The degree of fiscal and political decentralization may also be related to regional resilience. In fact, the transfer of resources and powers from central to subnational governments is often justified as a means to improve economic performance, both at the local and at the aggregate level, pushing the traditional arguments of safeguarding local identity or culture into the background (Rodríguez-Pose and Sandall, 2008). This supposed economic dividend is based on the so-called "decentralization theorem", which states that subnational tiers of government are more capable than central governments to tailor the provision of public goods and services to the needs of citizens due to the existence of informational advantages and a better insight into the preferences of the local population (Tibebout, 1956; Oates, 1972). This implies that, in the absence of interjurisdictional spillover effects and large scale economies, decentralization can lead

\footnotetext{
${ }^{16}$ The main results of the paper hold whether we use $R \& D$ expenditure instead of the number of patents to capture the degree of innovation capacity.
} 
to efficiency gains in the allocation of resources at the local level (Ezcurra, 2017). Moreover, decentralization should allow subnational governments to adopt specific policies in order to mitigate the effects on the local economy of adverse shocks.

Nevertheless, the literature also warns about the potential risks of decentralization for economic performance. Thus, the needs and preferences for public goods and services may not differ significantly across regions within a country, which casts doubts on the validity of the decentralization theorem. At the same time, capacity constraints may limit the ability of subnational governments to make the most from devolution. Furthermore, poorer regions often must face an additional disadvantage in the provision of public goods and services due to the lack of suitable human resources to develop an efficient administration (Treisman, 2007). Additionally, subnational governments may be more vulnerable to capture by local interests, generating greater corruption, clientelism and nepotism (Rodríguez-Pose and Ezcurra, 2011). This latter point is especially relevant in our context, as it suggests the possible existence of a connection between decentralization and quality of government (Fisman and Gatti, 2002; Enikolopov and Zhuravskaya, 2007). This raises the possibility that the measure of governance used in our analysis is really capturing the effect on regional resilience of decentralization. In order to test whether this is the case, we should control for the degree of decentralization in the sample regions. To do this, we resort to an indicator of regional economic self-rule proposed by Sorens (2014), which captures the degree of authority exercised by a regional government over those who live in its territory. The indicator is constructed using data drawn from the Regional Authority Index (RAI) developed by Hooghe et al. (2010), and combines information on the degree of fiscal and political decentralization in the sample regions (see Table A1 in the online Appendix for further details). Bearing 
in mind the previous discussion, we consider the possible presence of a non-linear link between decentralization and regional resilience. To that end, we include in the list of regressors the indicator of regional self-rule and its square.

\section{Other factors}

In addition to the different factors discussed above, agglomeration economies and the demographic structure may have influence on regional resilience. Agglomeration economies arise when people and firms locate near one another together in cities and industrial clusters, which ultimately implies transport costs savings (Glaeser, 2010). The impact of agglomeration economies in regional resilience is not clear beforehand. On the one hand, highly urbanized areas may increase the probability of matching job seekers and firms, improving the functioning of regional labour markets in an economic downturn. However, negative effects and agglomeration diseconomies may arise if the time spent by workers to collect information about the vacancies on the job market rises or if problems of crowding and congestion increase excessively (Fujita and Thisse, 2002; Rios, 2017). Taking this into account, employment density is used in our analysis as a proxy for the relevance of agglomeration economies in any given region.

Regional resilience may also be related to the demographic structure, which is directly related to the availability of adequate labour supply for the different economic activities and to the degree of social vulnerability (Groenewold, 1997; Bigos et al., 2013). The expected effects of the demographic structure on regional resilience are theoretically ambiguous. Thus, regions with older populations are at higher technological risk than regions with younger populations due to the skill obsolescence effect (Dixon, 2003). 
Moreover, older populations are likely to be less flexible and mobile than younger ones, which should amplify the skill miss-match between labour demand and supply along the geographical dimension, thus increasing regional labour market vulnerability. In addition, the empirical evidence shows that older populations are less prone to innovation (Aksoy et al., 2015) and less productive (Lovasz and Rigo, 2013), which should have a negative effect on the ability to develop new growth paths once a region has been hit by a recessionary shock. This suggests that older populations may have lower levels of resilience than younger ones. However, there are also arguments that indicate that the opposite may also be true. If different cohorts have different levels of productivity, it is likely that age structure may affect economic development paths. At this point, the literature stresses that a worker's productivity systematically varies over her working life for reasons such as the accumulation of experience over time, depreciation of knowledge, and age-related trends in physical and mental capabilities (Aiyar et al., 2016). In this regard, a more mature labour force may have higher average levels of work experience, with potentially positive effects on productivity (Disney, 1996; Burtless, 2013). Moreover, a large young cohort relative to the parental cohort results in higher competition for jobs, lower opportunities for promotion, and higher tightness of the labour market (Easterlin, 1978). In fact, younger populations might be trapped in the lower end of the labour market with less on-the-job training, lower wages and worse career prospects, experiencing long spells of joblessness and high risk of exclusion and vulnerability to shocks. In order to control for the role of age structure, we include in our econometric model the share of population aged 15-24 years, and the share of population aged 55-64 years. 


\section{Country dummies}

Figure 1 shows that regional resilience in the EU is clearly affected by national patterns (Crescenzi et al., 2016a; Giannakis and Bruggeman, 2017). In view of this, our baseline specification also incorporates country dummies to ensure that the observed link between quality of government and regional resilience is not simply capturing the latent influence of institutional, economic and/or historical factors at the national level. Accordingly, our analysis focuses on the ability of the quality of government to explain variations in regional resilience within the EU countries.

\subsection{The spatial weights matrix}

The estimation of the $\operatorname{SARAR}(1,1)$ model described above requires to define previously a spatial weights matrix. Given that this is a critical issue in spatial econometric modelling (Corrado and Fingleton, 2012), we consider a broad range of alternative specifications of $\mathbf{W}$. Thus, we begin by constructing a spatial weights matrix based on the concept of first order contiguity, according to which $w_{i j}=1$ if regions $i$ and $j$ are physically adjacent and 0 otherwise. We also consider several matrices based on the k-nearest neighbours $(k=5,10,15,20,25)$, computed from the great circle distance between the centroids of the various regions (Le Gallo and Ertur, 2003). Additionally, we construct various exponential decay and inverse distance matrices whose off-diagonal elements are defined respectively by $w_{i j}=\exp \left(-\theta d_{i j}\right)$ for $\theta=0.01,0.05$, and $w_{i j}=\frac{1}{d_{i j}^{\alpha}}$ for $\alpha=2$ with cut-offs at the first, second and third quartile of the geographical distance between regions. As an alternative, we also consider inverse linear distance weights matrices with cuff-offs at 750, 1,000 and 1,500 kilometres. As can be observed, the different matrices 
described above are based in all cases on the geographical distance between the sample regions, which in itself is strictly exogenous. Furthermore, as is common practice in applied research, all the matrices are row-standardized, so that it is relative, and not absolute, distance which matters.

In the literature there are different criteria to determine the spatial weights matrix that best describes the data. One of the most widely used approach is to compare the log-likelihood function values. Nevertheless, this approach has been criticized because it only finds a local maximum among competing models and it may be the case that the correctly specified $\mathbf{W}$ is not included (Vega and Elhorst, 2014). As an alternative criterion, Elhorst et al. (2013) suggest to select the model with the lowest parameter estimate of the residual variance. Table 1 shows that, according to these criteria, the most appropriate matrix in our context is that based on the 15-nearest neighbours. Therefore, this is the spatial weights matrix used in the rest of the paper.

INSERT TABLE 1 AROUND HERE

\section{Empirical findings}

\subsection{Main results}

Table 2 presents the results obtained when different versions of the $\operatorname{SARAR}(1,1)$ model in equations (2) and (3) are estimated by GS2SLS for the case of heteroskedastic innovations of unknown form in the disturbance process. The estimated coefficient of the 
spatial lag of the dependent variable is in all cases positive and statistically significant at the $1 \%$ level, indicating the existence of strong spatial dependence in regional resilience. In other words, the capacity of resistance to the Great Recession for a given region is positively affected by resilience in neighbouring regions. This is in line with the information provided by Figure 3, and highlights the need to take into account spatial effects when modelling regional resilience in the EU. Focussing on the major aim of the paper, the main finding is that the coefficient of the measure of quality of government is in all cases positive and statistically significant at the $1 \%$ level. This means that higher quality of government is associated with greater regional resilience, which is consistent with most of the arguments laid down in section 2 and the preliminary evidence displayed in Figure 2. In fact, this result is not affected by the inclusion in the analysis of the different controls described in section 4.2, confirming its robustness and showing that the observed connection between quality of government and regional resilience is not simply a spurious correlation resulting from the omission of these covariates. In fact, the magnitude of the coefficient of the measure of quality of government tends to be relatively stable in the various specifications of the $\operatorname{SARAR}(1,1)$ model considered in Table 2, which increases our confidence in suggesting that the relationship between governance and regional resilience is not driven by an omitted variable.

\section{INSERT TABLE 2 AROUND HERE}

In any case, the information provide by Table 2 should be treated with caution because the presence of the spatial lag of the dependent variable in the list of regressors complicates the interpretation of the coefficient estimates. As shown by LeSage and Pace 
(2009, pp. 33-42), in this type of spatial model a change in a particular explanatory variable in region $i$ has a direct effect on the dependent variable in that region, but also an indirect effect on the remaining regions. In our context, the direct effect reflects the average change in the measure of resistance to the crisis in a particular region caused by a one unit change in that region's explanatory variable. In turn, the indirect effect can be defined as the aggregate impact on resilience in a specific region caused by the change in an explanatory variable in all other regions or, alternatively, as the impact of changing an explanatory variable in a particular region on resilience in the remaining regions. ${ }^{17}$ Finally, the total effect is the sum of the direct and indirect effects.

Table 3 shows the direct, indirect and total effects calculated from the $\operatorname{SARAR}(1$, 1) model with the full set of controls (column 6 of Table 2). ${ }^{18}$ The results confirm the existence of a positive and statistically significant relationship between quality of government and regional resilience, thus reinforcing our previous findings. In particular, our estimate of the total effect reveals that increasing the measure of quality of government by one standard deviation is associated with an increase in the indicator of resilience of around 4.7 points, which is, for example, the difference between Franche-Comté (FR43) and Åland (FI2). As can be observed in Table 3, most of this total effect is due to the direct effect of governance on regional resilience. However, the indirect effect is also positive and statistically significant. This implies that the ability of resistance to the crisis of a particular region depends partly on the quality of government in neighbouring regions, which highlights again the empirical relevance of spatial spillovers in this context.

\footnotetext{
${ }^{17}$ LeSage and Pace (2009) show that the numerical magnitudes of these two calculations are identical due to symmetries in computation.

${ }^{18}$ See LeSage and Pace (2009, pp. 36-37) for further details on the calculation of these effects.
} 


\section{INSERT TABLE 3 AROUND HERE}

With respect to the various control variables included in our baseline model, Table 3 shows that the employment share in agriculture is positively associated with regional resilience. This seems to indicate that regions with a relatively important presence of farming activities are more resilient, which may be related to the high degree of protection that characterizes agricultural markets in the EU (Rodríguez-Pose and Fratesi, 2007). At the same time, the endowment of human capital appears as an important factor in explaining the ability of regional labour markets to react to recessionary shocks. This result is consistent with previous findings on the determinants of regional resilience (e.g. Di Caro, 2017; Giannakis and Bruggeman, 2017), and confirms that human capital is key in providing a generally innovation-prone environment that allows regional economies to identify creative solutions to external disturbances (Crescenzi et al., 2016a). Interestingly, spatial spillovers also affect the connection between human capital and regional resilience. In fact, our estimates reveal that the reaction to the Great Recession of a particular region is positively influenced by the endowment of human capital in neighbouring regions. Furthermore, the information provided by Table 3 shows the existence of a U-shaped relationship between regional autonomy and resilience. This implies that the transfer of resources and power from central to subnational governments initially exerts a negative impact on regional resilience. However, beyond a certain level, the relationship becomes positive, indicating that the degree of self-rule increases regional resilience. According to our estimates, the turning point is situated slightly below the level of autonomy experienced by Austrian regions. The remaining covariates are not statistically significant at conventional levels. 


\subsection{Robustness checks}

The analysis performed so far reveals the existence of a positive association between quality of government and regional resilience. In this section we investigate the robustness of this finding.

\section{Endogeneity of government quality}

A potential concern with our previous results has to do with the possible endogeneity of governance in this context. Regional resilience may by determined by the quality of government, but the quality of government may, in turn, be influenced by regional economic performance, giving rise to a reverse causality problem. Moreover, the indicator of quality of government used in the paper may be affected by measurement errors. Finally, although our baseline specification includes a substantial set of controls and country dummies, we cannot definitely rule out the possible existence of an omitted determinant of regional resilience correlated with government performance. In view of these potential problems, we now treat the measure of quality of government as endogenous. Nevertheless, a literature review shows that it is really difficult to identify variables that affect governance and not regional labour market performance. Faced with this problem, we follow the strategy adopted by Kelejian et al. (2013) and use as instruments the linearly independent columns of $\left(\mathbf{X}, \mathbf{W X}, \mathbf{W}^{2} \mathbf{X}\right) \cdot{ }^{19}$ Table 4 presents the effects on regional resilience of the different variables included in our baseline model when we use the set of instruments just described in order to address the potential

\footnotetext{
${ }^{19}$ It is standard practice in the literature to use this type of instruments to estimate models similar to ours. See Kelejian and Prucha (1998), Das et al. (2003) or Arraiz et al. (2010) for further details.
} 
endogeneity of the quality of government. ${ }^{20}$ As can be seen, the different effects of the quality of government on regional resilience continue to be positive and statistically significant in all cases, in line with our previous findings. This suggests that the results in Tables 2 and 3 are not driven by the potential endogeneity of the measure of quality of government.

\section{INSERT TABLE 4 AROUND HERE}

\section{Alternative estimation strategies and spatial models}

We now examine whether the results in section 5.1 are robust to the employment of an alternative method to estimate the $\operatorname{SARAR}(1,1)$ model in equations $(2)$ and (3). With this purpose, we repeat the previous analysis using a quasi-maximum likelihood (QML) estimator in lieu of the GS2SLS estimator used so far. Table 5 shows that the observed relationship between quality of government and regional resilience remains unaltered when we use this alternative estimation strategy. That said, it is important to recall that these estimates should be treated with caution, since if the innovations in the disturbance process in equation (3) are hetoroskedastic, the QML estimator can produce inconsistent results (Kelejian and Prucha, 2010). In any case, the magnitude of the impact of the quality of government on regional resilience is very similar to that obtained when the GS2SLS estimator is used (Table 3).

\section{INSERT TABLE 5 AROUND HERE}

\footnotetext{
${ }^{20}$ The different effects calculated in this section are derived from the estimates in column (6) of Tables A3-A9 in the online Appendix.
} 
We also explore to what extent our results depend on the specific spatial model used to investigate the link between quality of government and regional resilience. As discussed in section 4.1, in our particular context there are various reasons to justify the employment of a first-order SARAR model as our baseline specification. However, in view that the results in Table 2 reveal that the spatial autocorrelation coefficient is not statistically significant, we now proceed to estimate a spatial autoregressive model. Furthermore, as an additional robustness check, we also consider the possibility that regional resilience may be directly affected by conditions in neighbouring regions rather than indirectly by the effect of these conditions on the resilience of neighbouring regions. In order to examine this issue, we add spatial lags of the various explanatory variables as additional regressors in equation (2), which leads to the so-called spatial Durbin model. The results in Table 6 reveal that our main findings still hold, regardless of the spatial model considered. In all cases there is a positive and statistically significant association between quality of government and the ability of regional labour markets to react to the crisis. Nevertheless, it is interesting to note that in the spatial Durbin model, the indirect effect of governance on regional resilience is statistically significant only at the $10 \%$ level (see also Table A6 in the online Appendix for further details). This seems to suggest that the spatial spillovers induced by the quality of government mainly operate in an indirect way through the impact of governance on the resilience of neighbouring regions, which supports the employment of a SARAR model in this context.

INSERT TABLE 6 AROUND HERE 


\section{Alternative dimensions of the quality of government}

As stated in section 3, our measure of the quality of government, the EQI, is based on different surveys whose questions are centred on three concepts related to different aspects of governance: the quality, impartiality and level of corruption in education, public health care and law enforcement. Nevertheless, although they are positively correlated, it is not clear a priori that these three dimensions of governance affect regional resilience in the same way. For this reason, and in order to complement our previous analysis, we now resort to the information provided by the EQI to examine separately the role played in this context by the quality, impartiality and degree of corruption in the public services mentioned above. The results displayed in Table 7 show that these three aspects of the quality of government exert a positive and statistically significant effect on regional resilience, in line with our previous findings. ${ }^{21}$ In fact, according to our estimates, the quantitative impact is very similar in all cases, which indicates that the observed connection between governance and regional resilience is not driven by a particular dimension of the quality of government.

\section{INSERT TABLE 7 AROUND HERE}

\footnotetext{
${ }^{21}$ This finding still holds when we treat the various dimensions of quality of government as endogenous using the instruments described above. See Tables A10-A13 in the online Appendix for further details.
} 


\section{Conclusions}

This paper has examined the relationship between quality of government and regional resilience in the EU during the Great Recession. The results show that the quality of government is an important factor when shaping the regional reactions to the crisis in the EU. Our estimates reveal that higher quality of government is associated with greater regional resilience during the Great Recession. This is partly due to the role played in this context by spatial spillovers induced by the quality of government in neighbouring regions. The observed connection between governance and regional resilience is robust to the inclusion in the analysis of different explanatory variables that may affect both government quality and regional resilience. Likewise, our findings do not depend on the specific dimension of governance considered, the estimation method or the econometric specification employed to capture the nature of spatial spillovers.

The results of the paper raise potentially important policy implications, especially at a time in which there is an active public debate about what are the most appropriate instruments to reduce the impact of recessionary shocks on regional economies. Our analysis suggests that improving the quality of government may contribute to increasing the ability of regions to react to economic downturns. Accordingly, when designing effective development strategies, policy makers should pay particular attention to the way in which authority is exercised by regional governments. However, improving the quality of government at the regional level may not be an easy task in the European setting. Thus, it is likely that public intervention in this context cannot be based on a "one size fits all" policy framework. Moreover, it is important to recall that the quality of government depends in turn on historical and cultural factors, which cannot be easily 
modified in the short run.

Additional extensions to our work are not difficult to conceive. For example, it would be interesting to extend the study period to the post-crisis years. Lack of regional data has prevented us from pursuing this issue, but addressing it may provide a more complete perspective about the nature of the relationship between governance and regional resilience. Further research will also have to pay special attention to the need to identify and study the various transmission channels which explain ultimately the effect of governance on regional economic performance. Only by addressing these issues, we will be able to have a more detailed understanding about the way in which the quality of government affects regional resilience.

\section{Acknowledgements}

The authors are grateful to two anonymous referees for their useful comments and suggestions to an earlier version of the paper.

\section{Funding}

This research has benefited from the financial support of the Spanish Ministry of Economy and Competitiveness (Projects ECO2015-64330-P and ECO2016-76681-R). 


\section{References}

Acemoglu, D., Johnson, S., Robinson, J., \& Thaicharoen, Y. (2003). Institutional causes, macroeconomic symptoms: Volatility, crises and growth. Journal of Monetary Economics, 50, 49-123.

Aghion, P., \& Saint-Paul, G. (1998). Virtues of bad times: Interaction between productivity growth and economic fluctuations. Macroeconomic Dynamics, 2, 322344.

Ahrend, R., \& Goujard, A. (2012). International capital mobility and financial fragility -Part 3. How do structural policies affect financial crisis risk? Evidence from past crises across OECD and emerging economies. OECD Economics Department Working Papers, No. 966.

Aidt, T. S. (2009). Corruption, institutions, and economic development. Oxford Review of Economic Policy, 25(2), 271-291.

Aiyar, S., Ebeke, C., \& Shao, X. (2016). The impact of workforce aging on European productivity. IMF Working Paper WP/16/238.

Aksoy, Y., Basso H. S., Grasl, T., \& Smith, R. (2015). Demographic structure and macroeconomic trends. Birkbeck Working Papers in Economics and Finance No. 1501.

Anselin, L. (1988). Spatial Econometrics: Methods and Models. Kluwer Academic Publishers, Dordrecht. 
Anselin, L., \& Florax, R. (1995). New Directions in Spatial Econometrics. Springer, London.

Arraiz, I., Drukker, D. M., Kelejian, H. H., \& Prucha, I. R. (2010). A spatial CliffOrd- type model with heteroskedastic innovations: Small and large sample results. Journal of Regional Science, 50(2), 592-614.

Baldwin, J. R., \& Brown, W. M. (2004). Regional manufacturing employment volatility in Canada: The effects of specialisation and trade. Papers in Regional Science, $83(3), 519-541$.

Bigos, M., Qaran, W., Fenger, M., Koster, F., Mascini P., \& van der Veen, R. (2013). Review essay on labour market resilience. INSPIRES Working Paper Series 2013 No. 1.

Bloom, N. (2009). The impact of uncertainty shocks. Econometrica, 77(3), 623-685.

Boeri, T., Garibaldi, P., \& Moen, E. R. (2012). The labour market consequences of adverse financial shocks. IZA Discussion Papers 6826, Institute for the Study of Labor (IZA).

Brakman, S., Garretsen, H., \& van Marrewijk, C. (2015). Regional resilience across Europe: On urbanisation and the initial impact of the great recession. Cambridge Journal of Regions, Economy and Society, 8(2), 225-240.

Burtless, G. (2013). The impact of population aging and delayed retirement on workforce productivity. Center for Retirement Research at Boston College Working Paper 2013-11. 
Caldera-Sánchez, A., \& Gori, F. (2016). Can reforms promoting growth increase financial fragility? An empirical assessment. OECD Economics Department Working Papers, ECO/WKP(2016)64.

Calderón, C., Duncan, R., \& Schimdt-Hebbel, K. (2016). Do good institutions promote counter-cyclical macroeconomic policies? Oxford Bulletin of Economic and Statistics, 78(5), 650-670

Campos, N., Estrin, S., \& Proto, E. (2010). Corruption as a barrier to entry: Theory and evidence. CEPR Discussion Paper 8061.

Capello, R., \& Caragliu, A. (2016). After crisis scenarios for Europe: Alternative evolutions of struc- tural adjustments, Cambridge Journal of Regions, Economy and Society, 9(1), 81-101.

Capello, R., Caragliu, A., \& Fratesi, U. (2015). Spatial heterogeneity in the costs of the economic crisis in Europe: Are cities sources of regional resilience? Journal of Economic Geography, 15(5), 951-972.

Chapple, K., \& Lester, W. T. (2010). The resilient regional labour market? The US case. Cambridge Journal of Regions, Economy and Society, 3(1), 85-104.

Charron, N., Dijkstra, L., \& Lapuente, V. (2014). Regional governance matters: quality of government within European Union member states. Regional Studies, 48(1), 68-90.

Charron, N., Dijkstra, L., \& Lapuente, V. (2015). Mapping the regional divide in Europe: A measure for assessing quality of government in 206 European regions. 
Social Indicators Research, 122(2), 315-346.

Christopherson, S., Clark, G. L., \& Whiteman, J. (2015). Introduction: The Euro crisis and the future of Europe. Journal of Economic Geography, 15(5), 843-853.

Corrado, L., \& Fingleton, B. (2012). Where is the Economics in Spatial Econometrics? Journal of Regional Science, 52(2), 210-239.

Crescenzi, R. (2009). Undermining the principle of territorial concentration? EU regional policy and the socio-economic disadvantage of European regions. Regional Studies, 43(1), 111-133.

Crescenzi, R., \& Rodríguez-Pose, A. (2011). Innovation and Regional Growth in the European Union. Springer-Verlag, Berlin.

Crescenzi, R., Luca, D., \& Milio, S. (2016a). The geography of the economic crisis in Europe: National macroeconomic conditions, regional structural factors and short-term economic performance. Cambridge Journal of Regions, Economy and Society, 9(1), 13-32.

Crescenzi, R., Di Cataldo, M., \& Rodríguez-Pose, A. (2016b). Government quality and the economic returns of transport infrastructure investment in European regions. Journal of Regional Science, 56(4), 555-582.

Crescenzi, R., Pietrobelli, C., \& Rabellotti, R. (2014). Innovation drivers, value chains and the geography of multinational corporations in Europe. Journal of Economic Geography, 14(6), 1053-1086.

Das, D., Kelejian, H., \& Prucha, I. (2003). Finite sample properties of estimators of 
spatial autoregressive models with autoregressive disturbances. Papers in Regional Science, 82(1), 1-26.

Davies, S. (2011). Regional resilience in the 2008-2010 downturn: comparative evidence from European countries. Cambridge Journal of Regions, Economy and Society, 4(3), 369-382.

Di Caro, P. (2017). Testing and explaining economic resilience with an application to Italian regions. Papers in Regional Science, 96(1), 93-113.

Disney, R. (1996). Can We Afford to Grow Older? A Perspective on the Economics of Aging. MIT Press, Cambridge.

Doran, J., \& Fingleton, B. (2016). Employment resilience in Europe and the 2008 economic crisis: Insights from micro-level data. Regional Studies, 50(4), 644-656.

Drukker, D. M., Egger, P., \& Prucha, I. R. (2013). On two-step estimation of a spatial autoregressive model with autoregressive disturbances and endogenous regressors. Econometric Reviews, 32(5-6), 686-733.

Easterlin, R. A. (1978). Demographic influences on economic stability: The United States experience. Population and Development Review, 4(1), 1-22.

Elhorst, P., Zandberg, E., \& De Haan, J. (2013). The impact of interaction effects among neighbouring countries on financial liberalization and reform: A dynamic spatial panel data approach. Spatial Economic Analysis, 8(3), 293-313.

Esfahani, H.S., \& Ramírez, M.T. (2003). Institutions, infrastructure, and economic growth. Journal of Development Economics, 70, 443-477. 
Enikolopov, R., \& Zhuravskaya, E. (2007). Decentralization and political institutions. Journal of Public Economics, 91(11-12), 2261-2290.

Ezcurra, R. (2011). Unemployment volatility and regional specialization in the European Union. Regional Studies, 45(8), 1121-1137.

Ezcurra, R. (2017). Is government decentralization useful in the fight against domestic terrorism? A cross-country analysis. Environment and Planning C: Politics and Space, 35(5), 872-897.

Fazio, G., \& Talamo, C. (2008). How "attractive" is good governance for FDI?, International Finance Review, 9 , pp. 33-54.

Fingleton, B., Garretsen, H., \& Martin, R. (2012). Recessionary shocks and regional employment: Evidence on the resilience of UK regions. Journal of Regional Science, 52(1), 109-133.

Fingleton, B., Garretsen, H., \& Martin, R. (2014). Shocking aspects of monetary union: The vulnerability of regions in Euroland. Journal of Economic Geography, 15(5), 907-934.

Fisman, R., \& Gatti, R. (2002). Decentralization and corruption: Evidence across countries. Journal of Public Economics, 83(3), 325-345.

Fratesi, U., \& Rodríguez-Pose, A. (2016). The crisis and regional employment in Europe: what role for sheltered economies? Cambridge Journal of Regions, Economy and Society, 9(1), 33-57.

Frenken, K., Van Oort, F., \& Verburg, T. (2007). Related variety, unrelated variety 
and regional economic growth. Regional Studies, 41(5), 685-697.

Fujita, M., \& Thisse, J. F. (2002). Economics of Agglomeration. Cambridge University Press, Cambridge.

Giannakis, E., \& Bruggeman, A. (2017). Determinants of regional resilience to economic crisis: a European perspective. European Planning Studies, 25(8), 13941415

Glaeser, E. L. (2010). Agglomeration Economies. The University of Chicago Press, Chicago.

Groenewold, N. (1997). Does migration equalise regional unemployment rates? Evidence from Australia. Papers in Regional Science, 76(1), 1-20.

Groot, S. P. T., Mohlmann, J. L., Garretsen, J. H., \& de Groot, H. L. F. (2011). The crisis sensitivity of European countries and regions: Stylized facts and spatial heterogeneity. Cambridge Journal of Regions, Economy and Society, 4(3), 437456.

Hall, R. E., \& Jones, J. I. (1999). Why do some countries produce so much more output per worker than others? The Quarterly Journal of Economics, 114(1), 83-116.

Hooghe, L., Marks, G., \& Schakel, A. H. (2010). The Rise of Regional Authority: A Comparative Study of 42 Democracies. Routledge, New York.

Kaufmann, D., \& Kraay, A. (2002). Growth without governance. Policy Research Working Paper Series 2928, The World Bank. 
Kaufmann, D., Kraay, A., \& Zoido-Lobatón, P. (1999). Governance matters. World Bank Policy Research Working Paper 2196, The World Bank.

Kelejian, H. H., \& Prucha, I. R. (1998). A generalized spatial two-stage least squares procedure for estimating a spatial autoregressive model with autoregressive disturbances, Journal of Real Estate Finance and Economics, 17(1), 99-121.

Kelejian, H. H., \& Prucha, I. R. (1999). A generalized moments estimator for the autoregressive parameter in a spatial model. International Economic Review, 40(2), 509-533.

Kelejian, H. H., \& Prucha, I. R. (2010). Specification and estimation of spatial autoregressive models with autoregressive and heteroskedastic disturbances. Journal of Econometrics, 157, 53-67.

Kelejian, H. H., Murrell, P., \& Shepotylo, O. (2013). Spatial spillovers in the development of institutions. Journal of Development Economics, 101, 297-315.

Ketterer, T. D., \& Rodríguez-Pose, A. (2018). Institutions vs. 'first-nature' geography: What drives economic growth in Europe's regions? Papers in Regional Science, 97(S1), S25-S62.

La Porta, R., López-de-Silanes, F., \& Zamarripa, G. (2003). Related lending. Quarterly Journal of Economics, 118(1), 231-267.

Lagravinese, R. (2015). Economic crisis and rising gaps North-South: Evidence from the Italian regions. Cambridge Journal of Regions, Economy and Society, 8(2), $331-342$. 
Le Gallo, J., \& Ertur, C. (2003). Exploratory spatial data analysis of the distribution of regional per capita GDP in Europe, 19801995. Papers in Regional Science, $82(2), 175-201$.

LeSage, J., \& Pace, R. K. (2009). An Introduction to Spatial Econometrics. Chapman and Hall, Boca Raton (FL).

Lovasz, A., \& Rigo, M. (2013). Vintage effects, ageing and productivity. Labour Economics, 22, 47-60.

Malizia E. E., \& Ke, S. (1993). The influence of economic diversity on employment and stability. Journal of Regional Science, 33(2), 221-235.

Martin, R. (2012). Regional economic resilience, hysteresis and recessionary shocks. Journal of Economic Geography, 12(1), 1-32.

Martin, R., \& Sunley, P. (2015). On the notion of regional economic resilience: Conceptualization and explanation. Journal of Economic Geography, 15(1), 1-42.

Martin, R., Sunley, P., Gardiner, B., \& Tyler, P. (2016). How regions react to recessions: Resilience and the role of economic structure. Regional Studies, 50(4), $561-585$.

Nistotskaya, M., Charron, N., \& Lapuente, V. (2015). The wealth of regions: Quality of government and SMEs in 172 European regions. Environment and Planning C: Government and Policy, 33(5), 1125-1155.

Nunn, N. (2007). Relationship-specificity, incomplete contracts, and the pattern of trade. Quarterly Journal of Economics, 122(2), 569-600. 
Oates, W. (1972). Fiscal Federalism. Harcourt Brace Jovanovich, New York.

OECD (2010). Moving Beyond the Job Crisis. Employment Outlook. OECD, Paris.

OECD (2017).OECD G20 Policy Paper on Economic Resilience and Structural Policies. OECD, Paris.

Oates, W. (1972). Fiscal Federalism. Harcourt Brace Jovanovich, New York.

Putnam, R. D. (2000). Bowling Alone: The Collapse and Revival of American Community. Simon \& Schuster, New York.

Rios, V. (2017). What drives unemployment disparities in European regions? A dynamic spatial panel approach. Regional Studies, 51(11), 1599-1611.

Rizzi, P., Graziano, P., \& Dallara, A. (2018). A capacity approach to territorial resilience: the case of European regions. The Annals of Regional Science, 60(2), 285-328.

Rodríguez-Pose, A., \& Cols, G. (2017). The determinants of foreign direct investment in sub-Saharan Africa: What role for governance? Regional Science Policy and Practice, 9(2), 63-81.

Rodríguez-Pose, A., \& Di Cataldo, M. (2015). Quality of government and innovative Performance in the regions of Europe. Journal of Economic Geography, 15(4), 673-706.

Rodríguez-Pose, A., \& Ezcurra, R. (2011). Is fiscal decentralization harmful for Economic growth? Evidence from the OECD countries. Journal of Economic Geog- 
raphy, 11(4), 619-643.

Rodríguez-Pose, A., \& Fratesi, U. (2007). Regional business cycles and the emergence of sheltered economies in the southern periphery of Europe. Growth and Change, $38(4), 621-648$.

Rodríguez-Pose, A., \& Garcilazo, E. (2015). Quality of government and the returns of investment: Examining the impact of cohesion expenditure in European regions 49(8), 1274-1290.

Rodríguez-Pose, A., \& Sandall, R. (2008). From identity to the economy: analyzing the evolution of the decentralisation discourse. Environment and Planning C: Government and Policy, 26(1), 54-72.

Rodrik, D., Subramanian, A., \& Trebbi, F. (2004). Institutions rule: The primacy of institutions over geography and integration in economic development. Journal of Economic Growth, 9(2), 131-165.

Schumpeter, J. A. (1942). Capitalism, Socialism, and Democracy. Harper \& Brothers, London.

Sondermann, D. (2016). Towards more resilient economies: The role of well-functioning economic structures. European Central Bank Working Paper Series, No 1984.

Sutherland, D., \& Hoeller, P. (2013). Growth-promoting policies and macroeconomic stability. OECD Economics Department Working Papers, No. 1091.

Sorens, J. (2011). Does fiscal federalism promote regional Inequality? An empirical analysis of the OECD, 1980-2005. Regional Studies, 48(2), 239-53. 
Staníčková, M., \& Melecký, L. (2018). Understanding of resilience in the context of regional development using composite index approach: the case of European Union NUTS-2 regions. Regional Studies, Regional Science, 5(1), 231-254.

Tanzi,V., \& Davoodi, H. (1997). Corruption, public investment, and growth. IMF Working Paper, No. 97/139.

Tiebout, C. M. (1956). A pure theory of local expenditures. Journal of Political Economy, 64(5), 416-424.

Treisman, D. (2007). The Architecture of Government. Rethinking Political Decentralization. Cambridge University Press, New York.

Trendle, B. (2006). Regional economic instability: The role of industrial diversification and spatial spillovers. The Annals of Regional Science, 40(4), 767-778.

Vega, S. H., \& Elhorst, P. (2014). Modelling regional labour market dynamics in space and time. Papers in Regional, 93(4), 819-841. 


\section{Figures and Tables}

Figure 1: Regional resilience in the EU during the Great Recession (2008-2013).

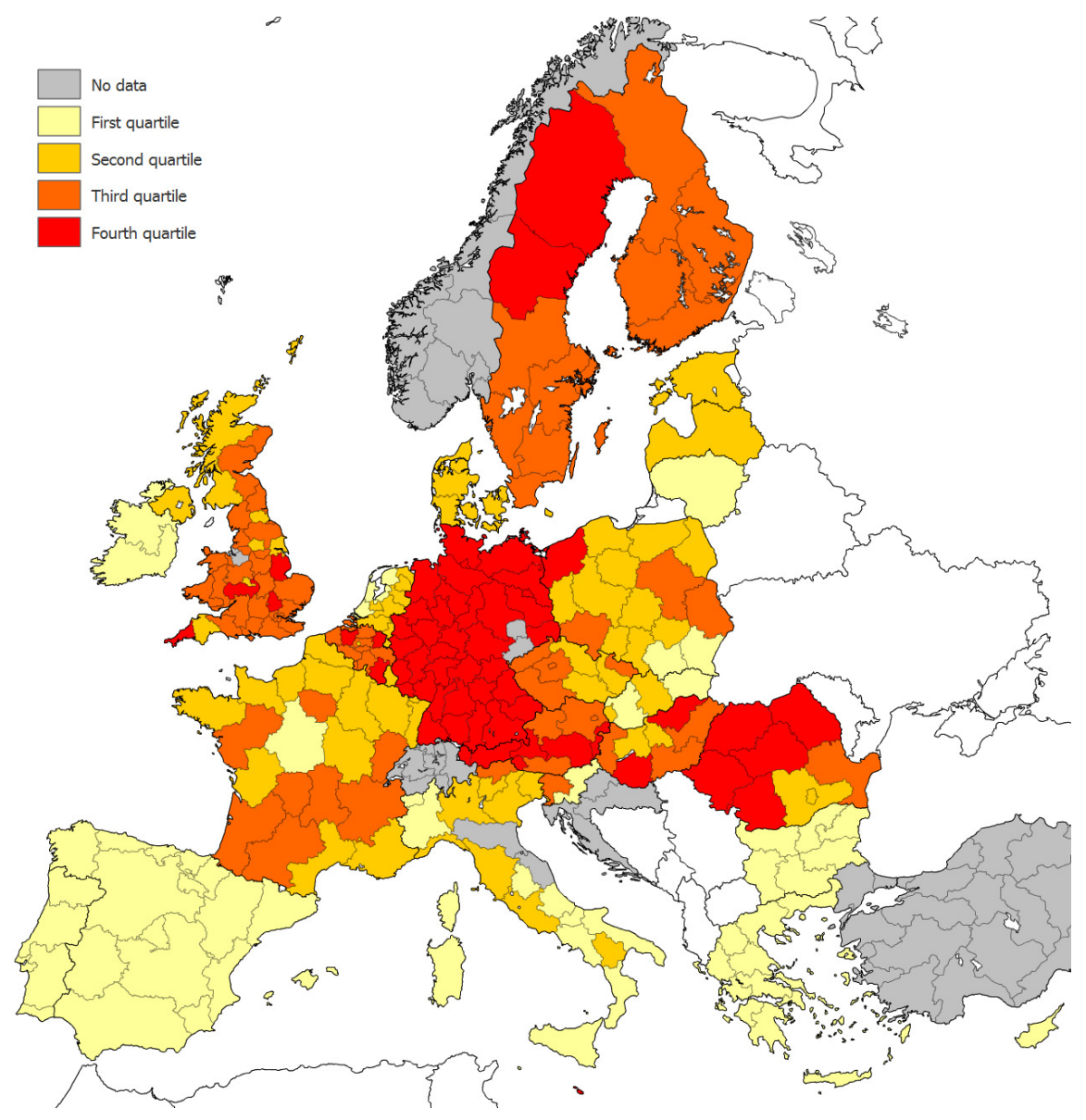

Source: Own elaboration based on Eurostat data. 
Figure 2: Quality of government and regional resilience in the EU during the Great Recession (2008-2013).

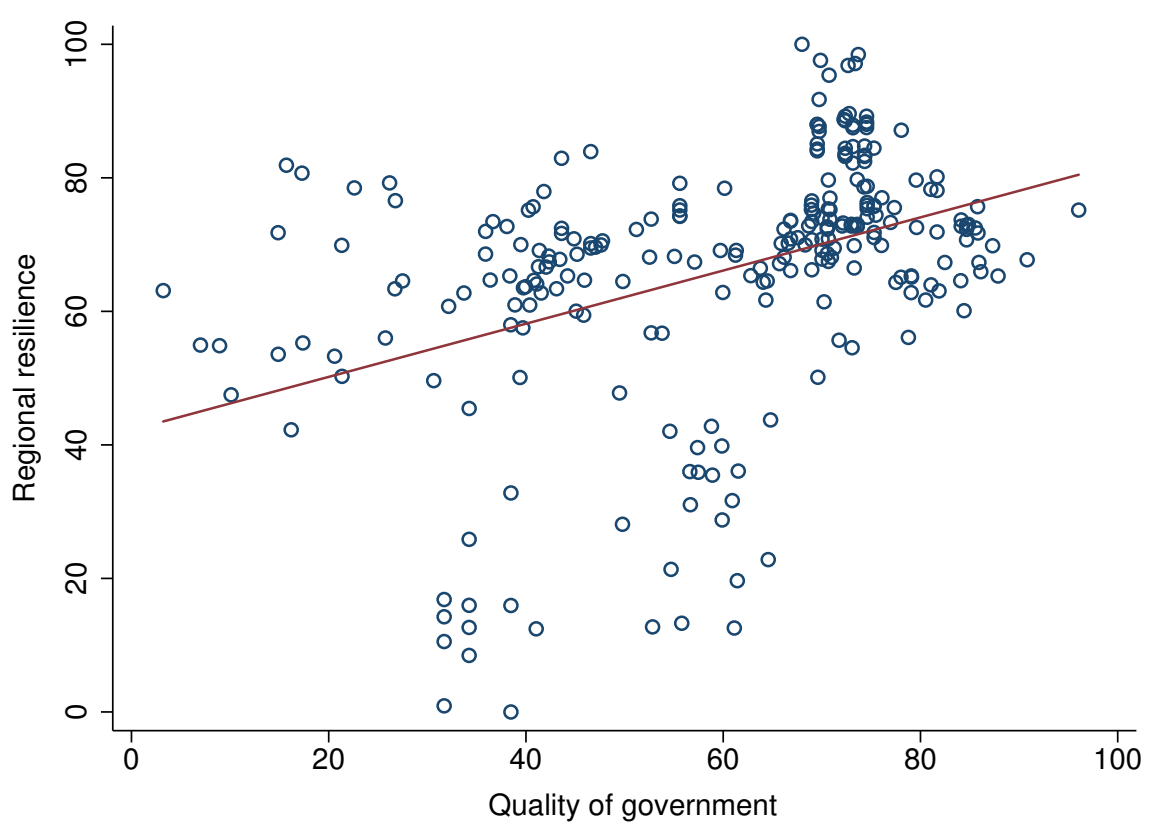


Figure 3: Regional resilience in the EU during the Great Recession (2008-2013): Do neighbouring regions matter?

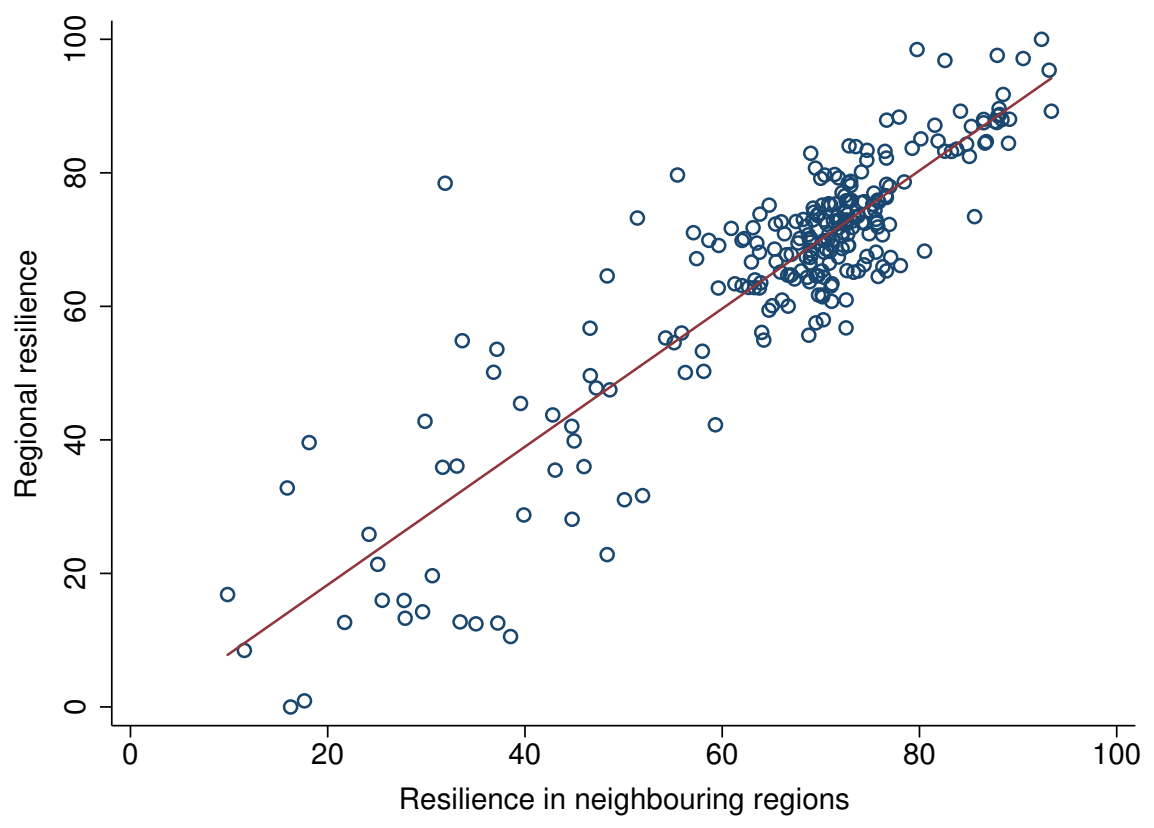


Table 1: Spatial weights matrix selection.

\begin{tabular}{|c|c|c|}
\hline & $\begin{array}{l}\text { Log-likelihood } \\
\text { function value }\end{array}$ & $\begin{array}{l}\text { Residual } \\
\text { variance }\end{array}$ \\
\hline First order contiguity & -687.973 & 29.590 \\
\hline 5-nearest neighbours & -683.698 & 28.593 \\
\hline 10-nearest neighbours & -683.688 & 28.593 \\
\hline 15-nearest neighbours & -679.254 & 27.184 \\
\hline 20-nearest neighbours & -680.946 & 27.542 \\
\hline 25-nearest neighbours & -681.140 & 27.520 \\
\hline $\exp -(\theta d), \theta=0.01$ & -689.139 & 29.497 \\
\hline $\exp -(\theta d), \theta=0.01$, cut-off at Q1 & -689.145 & 29.491 \\
\hline $\exp -(\theta d), \theta=0.01$, cut-off at Q2 & -689.123 & 29.528 \\
\hline $\exp -(\theta d), \theta=0.05$ & -688.617 & 29.315 \\
\hline $\exp -(\theta d), \theta=0.05$, cut-off at Q1 & -688.645 & 29.313 \\
\hline $\exp -(\theta d), \theta=0.05$, cut-off at Q2 & -688.624 & 29.320 \\
\hline $1 / d^{\alpha}, \alpha=2.00$ & -688.883 & 29.869 \\
\hline $1 / d^{\alpha}, \alpha=2.00$, cut-off at Q1 & -686.949 & 29.315 \\
\hline $1 / d^{\alpha}, \alpha=2.00$, cut-off at $\mathrm{Q} 2$ & -685.957 & 29.043 \\
\hline $1 / d^{\alpha}, \alpha=1.00$, cut-off at $750 \mathrm{~km}$ & -685.513 & 28.961 \\
\hline $1 / d^{\alpha}, \alpha=1.00$, cut-off at $1000 \mathrm{~km}$ & -682.945 & 28.355 \\
\hline $1 / d^{\alpha}, \alpha=1.00$, cut-off at $1500 \mathrm{~km}$ & -691.549 & 27.306 \\
\hline
\end{tabular}

Notes: Bayesian Markov Monte Carlo Chain (MCMC) routines developed by James LeSage are employed to carry out the estimation of the $\operatorname{SARAR}(1,1)$ model in equations $(2)$ and $(3)$ with the different spatial weights matrices considered. The full set of controls described in section 4.2 is included in all the estimations. Log-likelihood values reported in column (1) are obtained evaluating the likelihood of the $\operatorname{SARAR}(1,1)$ model at the posterior mean of the estimated parameter vector after 5,000 MCMC draws. 
Table 2: Quality of government and regional resilience: Baseline results.

\begin{tabular}{|c|c|c|c|c|c|c|}
\hline & (1) & (2) & (3) & (4) & $(5)$ & $(6)$ \\
\hline Neighbours' resilience & $\begin{array}{c}0.341^{* * *} \\
(0.082)\end{array}$ & $\begin{array}{c}0.393^{* * *} \\
(0.078)\end{array}$ & $\begin{array}{c}0.378^{* * *} \\
(0.078)\end{array}$ & $\begin{array}{c}0.330^{* * *} \\
(0.081)\end{array}$ & $\begin{array}{c}0.357^{* * *} \\
(0.080)\end{array}$ & $\begin{array}{c}0.407^{* * *} \\
(0.075)\end{array}$ \\
\hline Quality of government & $\begin{array}{c}0.162^{* * *} \\
(0.049)\end{array}$ & $\begin{array}{c}0.159^{* * *} \\
(0.053)\end{array}$ & $\begin{array}{c}0.184^{* * *} \\
(0.052)\end{array}$ & $\begin{array}{c}0.149^{* * *} \\
(0.049)\end{array}$ & $\begin{array}{c}0.173^{* * *} \\
(0.053)\end{array}$ & $\begin{array}{c}0.144^{* * *} \\
(0.055)\end{array}$ \\
\hline Agriculture & & $\begin{array}{c}0.121^{*} \\
(0.072)\end{array}$ & & & & $\begin{array}{l}0.171^{*} \\
(0.091)\end{array}$ \\
\hline Manufacturing & & $\begin{array}{l}-0.157^{*} \\
(0.086)\end{array}$ & & & & $\begin{array}{l}-0.100 \\
(0.115)\end{array}$ \\
\hline Non-market services & & $\begin{array}{l}-0.086 \\
(0.143)\end{array}$ & & & & $\begin{array}{l}-0.077 \\
(0.162)\end{array}$ \\
\hline Regional specialization & & $\begin{array}{c}0.207 \\
(0.274)\end{array}$ & & & & $\begin{array}{c}0.127 \\
(0.273)\end{array}$ \\
\hline Human capital & & & $\begin{array}{c}0.296^{* * * *} \\
(0.085)\end{array}$ & & & $\begin{array}{c}0.252^{* *} \\
(0.112)\end{array}$ \\
\hline Innovation & & & $\begin{array}{l}-0.981^{*} \\
(0.567)\end{array}$ & & & $\begin{array}{l}-0.488 \\
(0.636)\end{array}$ \\
\hline Regional autonomy & & & & $\begin{array}{c}-1.008^{* * *} \\
(0.206)\end{array}$ & & $\begin{array}{c}-0.993^{* * *} \\
(0.199)\end{array}$ \\
\hline Regional autonomy squared & & & & $\begin{array}{c}0.023^{* * *} \\
(0.005)\end{array}$ & & $\begin{array}{c}0.022^{* * *} \\
(0.005)\end{array}$ \\
\hline Employment density & & & & & $\begin{array}{c}0.153 \\
(0.565)\end{array}$ & $\begin{array}{l}-0.807 \\
(0.605)\end{array}$ \\
\hline Young population & & & & & $\begin{array}{l}-0.524 \\
(0.358)\end{array}$ & $\begin{array}{l}-0.418 \\
(0.313)\end{array}$ \\
\hline Old population & & & & & $\begin{array}{l}0.558^{*} \\
(0.303)\end{array}$ & $\begin{array}{c}0.131 \\
(0.275)\end{array}$ \\
\hline $\begin{array}{l}\text { Spatial autoregressive } \\
\text { coefficient }\end{array}$ & $\begin{array}{l}-0.192 \\
(0.284)\end{array}$ & $\begin{array}{l}-0.062 \\
(0.313)\end{array}$ & $\begin{array}{l}-0.418 \\
(0.320)\end{array}$ & $\begin{array}{l}-0.417 \\
(0.283)\end{array}$ & $\begin{array}{l}-0.334 \\
(0.286)\end{array}$ & $\begin{array}{l}-0.489 \\
(0.330)\end{array}$ \\
\hline Country dummies & Yes & Yes & Yes & Yes & Yes & Yes \\
\hline Pseudo R-squared & 0.924 & 0.927 & 0.927 & 0.928 & 0.928 & 0.935 \\
\hline Observations & 255 & 255 & 255 & 255 & 255 & 255 \\
\hline
\end{tabular}

Notes: The estimation method is GS2SLS with heteroskedastic innovations of unknown form in the disturbance process. The dependent variable is in all cases the index of regional resilience described in section 3. Standard errors in parentheses. All regressions include a constant (not shown). * Significant at $10 \%$ level, ${ }^{* *}$ significant at $5 \%$ level, ${ }^{* * *}$ significant at $1 \%$ level. 
Table 3: Baseline results: Direct, indirect and total effects.

\begin{tabular}{|c|c|c|c|}
\hline & $\begin{array}{l}\text { Direct } \\
\text { effects }\end{array}$ & $\begin{array}{l}\text { Indirect } \\
\text { effects }\end{array}$ & $\begin{array}{l}\text { Total } \\
\text { effects }\end{array}$ \\
\hline Quality of government & $\begin{array}{c}0.146^{* * *} \\
(0.056)\end{array}$ & $\begin{array}{c}0.097^{* *} \\
(0.041)\end{array}$ & $\begin{array}{c}0.243^{* * *} \\
(0.090)\end{array}$ \\
\hline Agriculture & $\begin{array}{c}0.174^{*} \\
(0.093)\end{array}$ & $\begin{array}{c}0.115 \\
(0.073)\end{array}$ & $\begin{array}{c}0.289^{*} \\
(0.161)\end{array}$ \\
\hline Manufacturing & $\begin{array}{c}-0.101 \\
(0.117)\end{array}$ & $\begin{array}{l}-0.067 \\
(0.083)\end{array}$ & $\begin{array}{l}-0.168 \\
(0.198)\end{array}$ \\
\hline Non-market services & $\begin{array}{l}-0.078 \\
(0.164)\end{array}$ & $\begin{array}{l}-0.052 \\
(0.112)\end{array}$ & $\begin{array}{l}-0.131 \\
(0.276)\end{array}$ \\
\hline Regional specialization & $\begin{array}{c}0.129 \\
(0.276)\end{array}$ & $\begin{array}{c}0.086 \\
(0.186)\end{array}$ & $\begin{array}{c}0.215 \\
(0.461)\end{array}$ \\
\hline Human capital & $\begin{array}{c}0.255^{* *} \\
(0.113)\end{array}$ & $\begin{array}{l}0.169 * \\
(0.093)\end{array}$ & $\begin{array}{c}0.424^{* *} \\
(0.198)\end{array}$ \\
\hline Innovation & $\begin{array}{c}-0.494 \\
(0.645)\end{array}$ & $\begin{array}{l}-0.328 \\
(0.449)\end{array}$ & $\begin{array}{c}-0.822 \\
(1.087)\end{array}$ \\
\hline Regional autonomy & $\begin{array}{c}-1.006^{* * *} \\
(0.202)\end{array}$ & $\begin{array}{l}-0.669 \\
(0.255)\end{array}$ & $\begin{array}{c}-1.675^{* * *} \\
(0.411)\end{array}$ \\
\hline Regional autonomy squared & $\begin{array}{c}0.022^{* * *} \\
(0.005)\end{array}$ & $\begin{array}{c}0.015 \\
(0.006)\end{array}$ & $\begin{array}{c}0.037^{* * *} \\
(0.010)\end{array}$ \\
\hline Employment density & $\begin{array}{l}-0.818 \\
(0.613)\end{array}$ & $\begin{array}{l}-0.543 \\
(0.459)\end{array}$ & $\begin{array}{l}-1.361 \\
(1.055)\end{array}$ \\
\hline Young population & $\begin{array}{l}-0.424 \\
(0.317)\end{array}$ & $\begin{array}{l}-0.282 \\
(0.223)\end{array}$ & $\begin{array}{l}-0.705 \\
(0.530)\end{array}$ \\
\hline Old population & $\begin{array}{c}0.133 \\
(0.279)\end{array}$ & $\begin{array}{c}0.088 \\
(0.186)\end{array}$ & $\begin{array}{c}0.222 \\
(0.464)\end{array}$ \\
\hline
\end{tabular}

Notes: The different effects are calculated from the estimates in column (6) of Table 2. The dependent variable is in all cases the index of regional resilience described in section $3 .{ }^{*}$ Significant at $10 \%$ level, ${ }^{* *}$ significant at $5 \%$ level, ${ }^{* * *}$ significant at $1 \%$ level. 
Table 4: Robustness analysis: Endogeneity of the quality of government.

\begin{tabular}{lccc}
\hline \hline & $\begin{array}{c}\text { Direct } \\
\text { effects }\end{array}$ & $\begin{array}{c}\text { Indirect } \\
\text { effects }\end{array}$ & $\begin{array}{c}\text { Total } \\
\text { effects }\end{array}$ \\
\hline Quality of government & $0.162^{* *}$ & $0.104^{* *}$ & $0.266^{* *}$ \\
& $(0.069)$ & $(0.047)$ & $(0.109)$ \\
Agriculture & $0.168^{*}$ & 0.107 & $0.275^{*}$ \\
Manufacturing & $(0.091)$ & $(0.069)$ & $(0.155)$ \\
Non-market services & -0.097 & -0.062 & -0.159 \\
Regional specialization & $(0.119)$ & $(0.081)$ & $(0.198)$ \\
Human capital & -0.070 & -0.045 & -0.115 \\
Innovation & $(0.168)$ & $(0.110)$ & $(0.278)$ \\
Regional autonomy & 0.128 & 0.082 & 0.210 \\
& $(0.274)$ & $(0.178)$ & $(0.452)$ \\
Regional autonomy squared & $0.257^{* *}$ & $0.164^{*}$ & $0.421^{* *}$ \\
& $(0.114)$ & $(0.090)$ & $(0.195)$ \\
Employment density & -0.518 & -0.331 & -0.848 \\
& $(0.650)$ & $(0.436)$ & $(1.080)$ \\
Young population & $-1.008^{* * *}$ & $-0.644^{* * *}$ & $-1.652^{* * *}$ \\
& $(0.203)$ & $(0.248)$ & $(0.406)$ \\
Old population & $(0.005)$ & $0.014^{* *}$ & $0.037^{* * *}$ \\
& -0.768 & $(0.006)$ & $(0.010)$ \\
& $(0.632)$ & $(0.452)$ & $(1.069)$ \\
\hline \hline & -0.399 & -0.255 & -0.654 \\
& $(0.320)$ & $(0.216)$ & $(0.528)$ \\
& 0.164 & 0.105 & 0.269 \\
& $(0.289)$ & $(0.185)$ & $(0.472)$ \\
\hline
\end{tabular}

Notes: The different effects are calculated from the estimates in column (6) of Table A3. The dependent variable is in all cases the index of regional resilience described in section $3 . *$ Significant at $10 \%$ level, ${ }^{* *}$ significant at $5 \%$ level, ${ }^{* * *}$ significant at $1 \%$ level. 
Table 5: Robustness analysis: Alternative estimation method. QML estimates.

\begin{tabular}{|c|c|c|c|}
\hline & $\begin{array}{l}\text { Direct } \\
\text { effects }\end{array}$ & $\begin{array}{c}\text { Indirect } \\
\text { effects }\end{array}$ & $\begin{array}{c}\text { Total } \\
\text { effects }\end{array}$ \\
\hline Quality of government & $\begin{array}{c}0.169^{* * *} \\
(0.055)\end{array}$ & $\begin{array}{c}0.088^{* * *} \\
(0.034)\end{array}$ & $\begin{array}{c}0.257^{* * *} \\
(0.081)\end{array}$ \\
\hline Agriculture & $\begin{array}{c}0.143^{*} \\
(0.080)\end{array}$ & $\begin{array}{c}0.075 \\
(0.051)\end{array}$ & $\begin{array}{c}0.217^{*} \\
(0.128)\end{array}$ \\
\hline Manufacturing & $\begin{array}{l}-0.103 \\
(0.090)\end{array}$ & $\begin{array}{l}-0.054 \\
(0.050)\end{array}$ & $\begin{array}{l}-0.157 \\
(0.139)\end{array}$ \\
\hline Non-market services & $\begin{array}{l}-0.055 \\
(0.126)\end{array}$ & $\begin{array}{l}-0.029 \\
(0.066)\end{array}$ & $\begin{array}{l}-0.084 \\
(0.192)\end{array}$ \\
\hline Regional specialization & $\begin{array}{c}0.083 \\
(0.238)\end{array}$ & $\begin{array}{c}0.043 \\
(0.123)\end{array}$ & $\begin{array}{c}0.126 \\
(0.361)\end{array}$ \\
\hline Human capital & $\begin{array}{c}0.252^{* *} \\
(0.099)\end{array}$ & $\begin{array}{l}0.131^{*} \\
(0.069)\end{array}$ & $\begin{array}{c}0.383^{* *} \\
(0.160)\end{array}$ \\
\hline Innovation & $\begin{array}{c}-0.542 \\
(0.667)\end{array}$ & $\begin{array}{c}-0.283 \\
(0.371)\end{array}$ & $\begin{array}{c}-0.825 \\
(1.031)\end{array}$ \\
\hline Regional autonomy & $\begin{array}{c}-1.087^{* * *} \\
(0.291)\end{array}$ & $\begin{array}{c}-0.567^{* *} \\
(0.231)\end{array}$ & $\begin{array}{c}-1.654^{* * *} \\
(0.479)\end{array}$ \\
\hline Regional autonomy squared & $\begin{array}{c}0.024^{* * *} \\
(0.007)\end{array}$ & $\begin{array}{c}0.013^{* *} \\
(0.005)\end{array}$ & $\begin{array}{c}0.037^{* * *} \\
(0.011)\end{array}$ \\
\hline Employment density & $\begin{array}{c}-0.649 \\
(0.663)\end{array}$ & $\begin{array}{l}-0.339 \\
(0.364)\end{array}$ & $\begin{array}{c}-0.987 \\
(1.017)\end{array}$ \\
\hline Young population & $\begin{array}{l}-0.434 \\
(0.310)\end{array}$ & $\begin{array}{c}-0.227 \\
(0.178)\end{array}$ & $\begin{array}{c}-0.661 \\
(0.480)\end{array}$ \\
\hline Old population & $\begin{array}{c}0.148 \\
(0.307) \\
\end{array}$ & $\begin{array}{c}0.077 \\
(0.162) \\
\end{array}$ & $\begin{array}{c}0.225 \\
(0.468) \\
\end{array}$ \\
\hline
\end{tabular}

Notes: The different effects are calculated from the estimates in column (6) of Table A4. The dependent variable is in all cases the index of regional resilience described in section $3 .{ }^{*}$ Significant at $10 \%$ level, ${ }^{* *}$ significant at $5 \%$ level, ${ }^{* * *}$ significant at $1 \%$ level. 
Table 6: Robustness analysis: Alternative spatial models.

\begin{tabular}{|c|c|c|c|c|c|c|}
\hline & \multicolumn{3}{|c|}{ Spatial autoregressive model } & \multicolumn{3}{|c|}{ Spatial Durbin model } \\
\hline & $\begin{array}{l}\text { Direct } \\
\text { effects }\end{array}$ & $\begin{array}{c}\text { Indirect } \\
\text { effects }\end{array}$ & $\begin{array}{c}\text { Total } \\
\text { effects }\end{array}$ & $\begin{array}{l}\text { Direct } \\
\text { effects }\end{array}$ & $\begin{array}{l}\text { Indirect } \\
\text { effects }\end{array}$ & $\begin{array}{c}\text { Total } \\
\text { effects }\end{array}$ \\
\hline \multirow[t]{2}{*}{ Quality of government } & $0.133^{* *}$ & $0.092^{* *}$ & $0.225^{* *}$ & $0.175^{* * *}$ & $0.930^{*}$ & $1.105^{* *}$ \\
\hline & $(0.056)$ & $(0.043)$ & $(0.093)$ & $(0.057)$ & $(0.542)$ & $(0.549)$ \\
\hline \multirow[t]{2}{*}{ Agriculture } & $0.198^{* *}$ & $0.137^{*}$ & $0.335^{*}$ & $0.163^{*}$ & -0.264 & -0.102 \\
\hline & $(0.096)$ & $(0.083)$ & $(0.172)$ & $(0.088)$ & $(0.661)$ & $(0.684)$ \\
\hline \multirow[t]{2}{*}{ Manufacturing } & -0.098 & -0.068 & -0.166 & -0.138 & 0.385 & 0.247 \\
\hline & $(0.124)$ & $(0.092)$ & $(0.214)$ & $(0.117)$ & $(0.684)$ & $(0.706)$ \\
\hline \multirow[t]{2}{*}{ Non-market services } & -0.107 & -0.074 & -0.182 & -0.074 & 2.184 & 2.110 \\
\hline & $(0.174)$ & $(0.126)$ & $(0.300)$ & $(0.141)$ & $(1.969)$ & $(1.970)$ \\
\hline \multirow[t]{2}{*}{ Regional specialization } & 0.213 & 0.147 & 0.360 & -0.090 & -6.505 & -6.595 \\
\hline & $(0.298)$ & $(0.212)$ & $(0.507)$ & $(0.270)$ & $(5.875)$ & $(5.937)$ \\
\hline \multirow[t]{2}{*}{ Human capital } & $0.248^{* *}$ & $0.172^{*}$ & $0.420 * * *$ & 0.166 & -1.362 & -1.196 \\
\hline & $(0.117)$ & $(0.101)$ & $(0.209)$ & $(0.126)$ & $(1.344)$ & $(1.423)$ \\
\hline \multirow[t]{2}{*}{ Innovation } & -0.356 & -0.247 & -0.603 & -0.060 & -5.197 & -5.257 \\
\hline & $(0.665)$ & $(0.475)$ & $(1.136)$ & $(0.750)$ & $(4.308)$ & $(4.542)$ \\
\hline \multirow[t]{2}{*}{ Regional autonomy } & $-0.903^{* * *}$ & $-0.624^{* *}$ & $-1.527 * * *$ & $-1.270^{* * *}$ & -8.679 & -9.948 \\
\hline & $(0.209)$ & $(0.265)$ & $(0.434)$ & 0.295 & $(5.878)$ & $(6.078)$ \\
\hline \multirow[t]{2}{*}{ Regional autonomy squared } & $0.020 * * *$ & $0.014^{* *}$ & $0.034^{* * *}$ & $0.029 * * *$ & 0.246 & 0.274 \\
\hline & $(0.005)$ & $(0.006)$ & $(0.010)$ & $(0.007)$ & $(0.165)$ & $(0.170)$ \\
\hline \multirow[t]{2}{*}{ Employment density } & -0.996 & -0.689 & -1.686 & 0.116 & 22.904 & 23.020 \\
\hline & $(0.629)$ & $(0.512)$ & $(1.114)$ & $(0.743)$ & $(16.143)$ & (16.611) \\
\hline \multirow[t]{2}{*}{ Young population } & -0.390 & -0.270 & -0.660 & -0.056 & -0.561 & -0.617 \\
\hline & $(0.325)$ & $(0.236)$ & $(0.552)$ & $(0.302)$ & $(1.872)$ & $(1.996)$ \\
\hline \multirow[t]{2}{*}{ Old population } & 0.098 & 0.068 & 0.165 & 0.278 & 4.068 & 4.347 \\
\hline & $(0.278)$ & $(0.192)$ & $(0.469)$ & $(0.306)$ & $(3.056)$ & $(3.160)$ \\
\hline
\end{tabular}

Notes: The different effects are calculated from the estimates in column (6) of Tables A5 and A6. The dependent variable is in all cases the index of regional resilience described in section $3 .{ }^{*}$ Significant at $10 \%$ level, ${ }^{* *}$ significant at $5 \%$ level, ${ }^{* * *}$ significant at $1 \%$ level. 


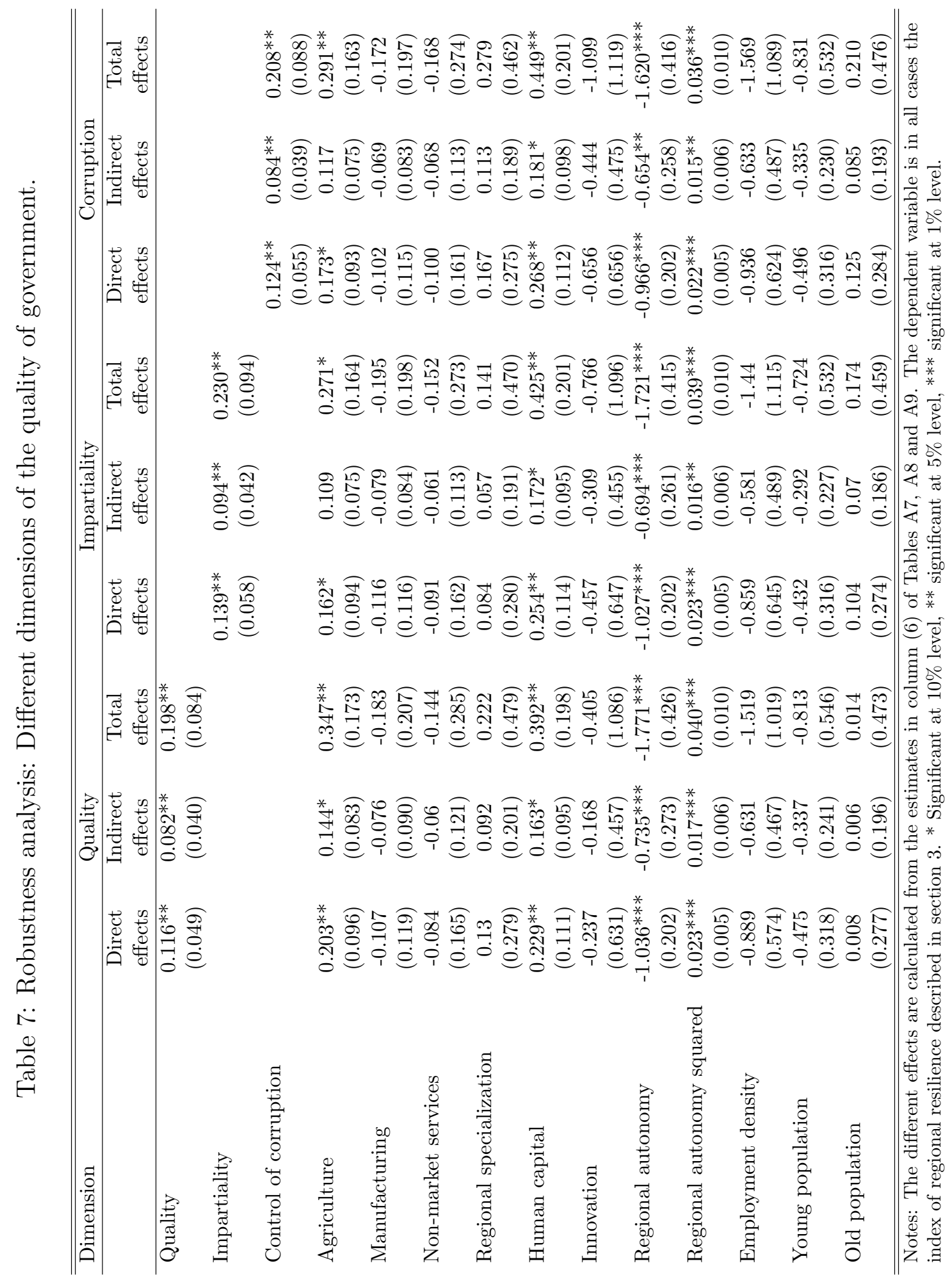

